\title{
Physicochemical and sensorial quality of banana genotypes ${ }^{1}$
}

\author{
Ronielli Cardoso Reis ${ }^{2}$, Eliseth de Souza Viana', \\ Jaciene Lopes de Jesus ${ }^{2}$, Tâmara Maria de Souza Santos ${ }^{3}$, Naiara Almeida de Oliveira ${ }^{3}$
}

\begin{abstract}
Despite the diversity of banana varieties in Brazil, only a few cultivars have the proper agronomic traits and fruit quality for commercial exploitation. This study aimed at evaluating the physicochemical traits and sensorial acceptance of banana genotypes, in order to identify those with potential for commercial growing. Six improved banana genotypes were assessed (BRS Maravilha, PC 0101, FHIA 18, TM 2803, YB 4203 and BRS Caipira), as well as three commercial cultivars (Grand Naine, Pacovan and Prata Anã). Analyses of peel and pulp color, peel thickness, pulp yield, moisture, $\mathrm{pH}$, soluble solids, titratable acidity, total carotenoids and sensorial acceptance were performed. The BRS Maravilha, FHIA 18, YB 4203 and BRS Caipira genotypes presented physicochemical traits similar to the Grand Naine, Pacovan and Prata Anã commercial cultivars. The BRS Maravilha and TM 2803 genotypes had sensorial acceptance similar to the Prata Anã and Grand Naine cultivars, and are therefore promising for commercial growing, with the advantage of being resistant to the black Sigatoka and Panama disease.
\end{abstract}

KEY-WORDS: Musa spp.; fruit quality; banana plant breeding.

\section{INTRODUCTION}

Banana (Musa spp.) is one of the most widely cultivated fruits in tropical countries, being the world's second leading fruit, in terms of production, with an annual output of 106 million metric tons. Brazil ranks fourth in the world, with approximately 6.9 million tons per year, from a planted area of 485,000 ha (FAO 2014).

Bananas are extremely popular due to their sensorial and nutritional characteristics. They are rich

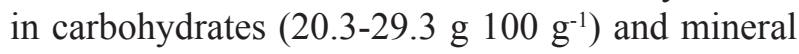

\section{RESUMO}

Qualidade físico-química e sensorial de genótipos de banana

Apesar da diversidade de variedades de banana existentes no Brasil, poucas cultivares apresentam características agronômicas e qualidade de fruto para exploração comercial. Objetivou-se avaliar as características físico-químicas e aceitação sensorial de genótipos de banana, visando à identificação daqueles com potencial para o mercado consumidor. Foram avaliados seis genótipos melhorados de banana (BRS Maravilha, PC 0101, FHIA 18, TM 2803, YB 4203 e BRS Caipira) e as cultivares comerciais Grand Naine, Pacovan e Prata Anã. Realizaram-se análises de cor da casca e da polpa, espessura da casca, rendimento, umidade, $\mathrm{pH}$, sólidos solúveis, acidez titulável, carotenoides totais e aceitação sensorial. Os genótipos BRS Maravilha, FHIA 18, YB 4203 e BRS Caipira apresentaram características físico-químicas semelhantes às das variedades comerciais Grand Naine, Pacovan e Prata Anã. Os genótipos BRS Maravilha e TM 2803 apresentaram aceitação sensorial semelhante à das variedades Prata Anã e Grand Naine, sendo, portanto, promissoras para o mercado, com a vantagem de serem resistentes a Sigatoka-negra e mal-do-Panamá.

PALAVRAS-CHAVE: Musa spp.; qualidade de fruto; melhoramento genético de bananeira.

salts such as calcium $\left(0.6-0.8 \mathrm{mg} 100 \mathrm{~g}^{-1}\right)$, magnesium (24-30 mg $\left.100 \mathrm{~g}^{-1}\right)$, phosphorus (16-29 mg $\left.100 \mathrm{~g}^{-1}\right)$ and potassium (264-387 mg $100 \mathrm{~g}^{-1}$ ) (Taco 2011). Together with rice, wheat and corn, banana is considered one of the most important global foods (Perrier et al. 2011).

Despite the wide range of varieties existing in Brazil, only a few cultivars have agronomic traits and fruit quality considered suitable for commercial exploitation (Roque et al. 2014). In the Brazilian market, the main commercial cultivars are from the subgroups Cavendish (Nanica, Nanicão and Grand

1. Manuscript received in Jan./2016 and accepted for publication in Mar./2016 (http://dx.doi.org/10.1590/1983-40632016v4639553).

2. Empresa Brasileira de Pesquisa Agropecuária (Embrapa Mandioca e Fruticultura), Cruz das Almas, BA, Brazil.

E-mails: ronielli.reis@embrapa.br, eliseth.viana@embrapa.br, jaciene.jesus@embrapa.br.

3. Universidade Federal do Recôncavo da Bahia, Centro de Ciências Agrárias, Ambientais e Biológicas, Cruz das Almas, BA, Brazil.E-mails: tamaramaria.bio@hotmail.com, naiara_moren@hotmail.com. 
Naine), Prata (Prata Anã and Pacovan), Maçã and Terra. These varieties are susceptible to black Sigatoka, yellow Sigatoka and/or Panama disease. One of the strategies to control these diseases is to use resistant cultivars, either by selection within existing genetic resources or by generating new hybrid cultivars (Amorim et al. 2011a). According to Silva et al. (2013), the cultivation of improved varieties can increase fruit yield and reduce production costs, especially with pesticides application.

Besides the development of cultivars that are resistant to pests and diseases, fruit physicochemical and sensorial assessment is essential in the process of selecting new varieties. Fruits must have size, shape, aroma, flavor, color and texture that satisfy the consumer preferences. Along with these aspects of resistance and fruit quality, genetic breeding programs need to search for desirable agronomic traits, such as plant size, fruit yield and drought and cold tolerance (Nomura et al. 2013, Roque et al. 2014).

This study aimed at assessing the physicochemical traits and sensorial acceptance, as well as the intention to purchase banana fruits from improved genotypes and commercial cultivars.

\section{MATERIAL AND METHODS}

The experiment was conducted in Cruz das Almas (12 $40^{\circ}$ '19'S, 39 $06^{\circ} 22^{\prime \prime} \mathrm{W}$ and altitude of $220 \mathrm{~m}$ ), Bahia State, Brazil, in an experimental area at Embrapa Mandioca e Fruticultura. The climate in the region is tropical humid, with an average annual temperature of $24.5^{\circ} \mathrm{C}$, relative humidity of $80 \%$ and average yearly rainfall of $1,249 \mathrm{~mm}$ (Agritempo 2013). The fruits were collected after 11-12 months of planting, from March to July 2012.
A randomized blocks design, with nine banana genotypes, in three blocks with four useful plants, was used. Six banana genotypes resistant to black Sigatoka, yellow Sigatoka and/or Panama disease (BRS Maravilha, YB4203, FHIA 18, PC 0101, TM 2803 and BRS Caipira) were evaluated, as well as three commercial cultivars (Prata Anã, Pacovan and Grand Naine) (Table 1). Three bunches were collected from each genotype, being each bunch from a distinct block, totaling three experimental replications. Fruits were collected at the ripeness stage 2 (mainly green peel, with traces of yellow) and evaluated in stage 6 (totally yellow peel), according to the Von Loeseck scale (PBMH \& PIF 2006).

The color of the fruits was evaluated using a Konica Minolta CR 400 chroma meter (CIELAB). The apparatus was calibrated with a white ceramic plate using the illuminant D65 $(z=93.6 ; x=0.3133$; $y=0.3195)$. The following chromatic attributes were evaluated: L* (lightness), $C^{*}$ (chroma/saturation) and $h^{*}$ (hue angle). The coordinate $L^{*}$ varies from pure black $(0)$ to pure white $(100)$; the hue angle $\left(\mathrm{h}^{*}\right)$ from pure red $\left(0^{\circ}\right)$, through pure yellow $\left(90^{\circ}\right)$, pure green $\left(180^{\circ}\right)$ and pure blue $\left(270^{\circ}\right)$; and the chroma $\left(\mathrm{C}^{*}\right)$ from 0 to 100 (the higher the value, the more intense the color) (Ramallo \& Mascheroni 2012). Three fruits from each bunch (second or third) were used to determine the color, with two measurements of the peel and two of the whole peeled fruit (middle region). The peel thickness was measured with a digital caliper and expressed in $\mathrm{mm}$. The pulp yield was calculated by the difference between the weight of the unpeeled and peeled fruits, and expressed in percent.

The physicochemical tests involved determining the titratable acidity ( $\%$ malic acid $)$, soluble

Table 1. Description of the banana genotypes evaluated.

\begin{tabular}{|c|c|c|c|}
\hline Genotype & Genome & Genealogy & Disease resistance \\
\hline BRS Maravilha & AAAB & Prata Anã Hybrid & Resistant to BS and PD \\
\hline PC 0101 & AAAB & Mutant of Caprichosa (Prata Comum x M53) & Resistant to BS and PD \\
\hline FHIA 18 & AAAB & Prata Anã Hybrid & $\begin{array}{l}\text { Resistant to BS, moderately resistant to YS } \\
\text { and susceptible to PD }\end{array}$ \\
\hline TM 2803 & AAAB & Mutant identified in the Amazonas State & Resistant to BS and PD \\
\hline YB 4203 & AAAB & Experimental hybrid (Yangambi no. 2 x M53) & Resistant to PD \\
\hline BRS Caipira & AAA & Ibota cultivar (West Africa) & Resistant to YS, BS and PD \\
\hline Grand Naine & AAA & Cavendish cultivar & Susceptible to YS and BS and resistant to PD \\
\hline Pacovan & $\mathrm{AAB}$ & Prata cultivar & Susceptible to YS, BS and PD \\
\hline Prata Anã & $\mathrm{AAB}$ & Traditional Prata cultivar & Susceptible to YS, BS and PD \\
\hline
\end{tabular}

BS: black Sigatoka; YS: yellow Sigatoka; PD: Panama disease. 
solids content ( $\left.{ }^{\circ} \mathrm{Brix}\right), \mathrm{pH}$ and moisture (\%) (IAL 2008). Additionally, spectrophotometry was used to determine the total carotenoids content $\left(\mu \mathrm{g} \mathrm{g}^{-1}\right)$ (Rodriguez-Amaya \& Kimura 2004).

The sensorial acceptance test was conducted with 50 tasters, who evaluated the color, aroma, flavor, texture and overall acceptance. The ripened fruits were cut crosswise into slices with thickness of about $3 \mathrm{~cm}$ and served individually and sequentially. The tasters rated each slice using a nine-point hedonic scale, ranging from "dislike extremely" (1) to "like extremely" (9). They also indicated the purchase intention, based on a five-point scale ranging from "certainly would not buy" (1) to "certainly would buy" (5) (Meilgaard et al. 2006). The data from the acceptance tasting are presented as percentage of approval (scores from 6 to 9 ) and the data on purchase intent are reported in percent.

The data were submitted to univariate analyses of variance and means were compared by the ScottKnott test, at $5 \%$, using the Sisvar software (Ferreira 2010). The data were also submitted to cluster analysis by the UPGMA method, considering the generalized Mahalanobis distance as the dissimilarity measure between genotypes, using the Genes statistical software (Cruz 2006). The number of groups was defined using the pseudo- $\mathrm{t}^{2}$ criterion (Gonçalves et al. 2008, Mingoti 2007), with the support of the R software (RDCT 2006).

\section{RESULTS AND DISCUSSION}

The fruit appearance evaluation involves a combination of geometric and physical traits, which have a strong influence on acceptability by consumers. The chromatic attributes, measured by the color parameters $\mathrm{L}^{*}, \mathrm{C}^{*}$ and $\mathrm{h}^{*}$, are presented in Table 2.

The PC 0101, TM 2803, YB 4203 and BRS Caipira genotypes had generally lighter peels than the other varieties, as can be noted from the higher values of $\mathrm{L}^{*}$. Regarding color intensity $\left(\mathrm{C}^{*}\right)$, there were no significant differences $(\mathrm{p}>0.05)$ between the genotypes peels, and the average value was 49.87 . For hue angle, the BRS Maravilha, PC 0101, FHIA 18 and Grand Naine genotypes showed values between $93.22^{\circ}$ and $97.39^{\circ}$, indicating that these genotypes peels are greenish yellow, when ripe. The hue angle allows the visualization of changes in the fruit color during the ripening stage, but genetic variation can also play a role on that, conferring different nuances to the peels (Castricini et al. 2015).

Regarding pulp color, the BRS Caipira and Grand Naine triploids presented the lowest values of $\mathrm{L}^{*}$, meaning darker pulp. In relation to $\mathrm{C}^{*}$, the highest values were observed for the YB 4203 and Grand Naine genotypes, indicating more intense pulp color, when compared to other genotypes. For h*, all the genotypes had values higher than 90, indicating that the pulp is greenish yellow.

The YB 4203 and BRS Caipira genotypes had the thinnest peels $(1.57 \mathrm{~mm}$ and $2.10 \mathrm{~mm}$, respectively) (Table 2). According to Matsuura et al. (2004), peel thickness is a quality considered relevant by most consumers of raw bananas. In a study on consumer preferences, the authors found that $45 \%$ of the respondents preferred fruits with thin peels $(2.0 \mathrm{~mm}), 42.2 \%$ preferred fruits having peels with medium thickness $(3.0 \mathrm{~mm})$ and only $12.81 \%$ expressed preference for fruits with thick

Table 2. Physical traits of the banana genotypes.

\begin{tabular}{|c|c|c|c|c|c|c|c|c|}
\hline \multirow{2}{*}{ Genotype } & \multicolumn{3}{|c|}{ Peel color } & \multicolumn{3}{|c|}{ Pulp color } & \multirow{2}{*}{$\begin{array}{l}\text { Peel thickness } \\
\text { (mm) }\end{array}$} & \multirow{2}{*}{$\begin{array}{c}\text { Yield } \\
(\%)\end{array}$} \\
\hline & $\mathrm{L}^{*}$ & $\mathrm{C}^{* \mathrm{~ns}}$ & $\mathrm{~h}^{*}$ & $\mathrm{~L}^{*}$ & $\mathrm{C}^{*}$ & $\mathrm{~h}^{*}$ & & \\
\hline BRS Maravilha & $64.79 \mathrm{~b}$ & 47.26 & $93.22 \mathrm{a}$ & $81.92 \mathrm{a}$ & $22.45 \mathrm{~b}$ & $94.32 \mathrm{~b}$ & $3.60 \mathrm{a}$ & $62.83 \mathrm{~b}$ \\
\hline PC0101 & $73.51 \mathrm{a}$ & 51.20 & $93.87 \mathrm{a}$ & $84.50 \mathrm{a}$ & $22.93 \mathrm{~b}$ & $96.62 \mathrm{a}$ & $3.26 \mathrm{a}$ & $61.65 \mathrm{~b}$ \\
\hline FHIA18 & $68.03 \mathrm{~b}$ & 49.03 & $97.39 \mathrm{a}$ & $82.77 \mathrm{a}$ & $22.73 \mathrm{~b}$ & $95.39 \mathrm{a}$ & $3.82 \mathrm{a}$ & $64.59 \mathrm{~b}$ \\
\hline TM 2803 & $70.41 \mathrm{a}$ & 52.28 & $91.73 \mathrm{~b}$ & $82.65 \mathrm{a}$ & $23.17 \mathrm{~b}$ & $96.53 \mathrm{a}$ & $3.65 \mathrm{a}$ & $61.98 \mathrm{~b}$ \\
\hline YB 4203 & $75.89 \mathrm{a}$ & 54.94 & $90.57 \mathrm{~b}$ & $83.75 \mathrm{a}$ & $26.03 \mathrm{a}$ & $95.55 \mathrm{a}$ & $1.57 \mathrm{~b}$ & $81.58 \mathrm{a}$ \\
\hline BRS Caipira & $73.80 \mathrm{a}$ & 42.88 & $88.98 \mathrm{~b}$ & $80.41 \mathrm{~b}$ & $22.53 \mathrm{~b}$ & $94.10 \mathrm{~b}$ & $2.10 \mathrm{~b}$ & $76.94 \mathrm{a}$ \\
\hline Grand Naine & $65.96 \mathrm{~b}$ & 49.46 & $95.17 \mathrm{a}$ & $79.88 \mathrm{~b}$ & $26.02 \mathrm{a}$ & $93.81 \mathrm{~b}$ & $3.14 \mathrm{a}$ & $69.21 \mathrm{~b}$ \\
\hline Pacovan & $65.05 \mathrm{~b}$ & 51.10 & $87.91 \mathrm{~b}$ & $82.87 \mathrm{a}$ & $23.95 \mathrm{~b}$ & $94.75 \mathrm{~b}$ & $2.75 \mathrm{a}$ & $65.28 \mathrm{~b}$ \\
\hline Prata Anã & $68.03 \mathrm{~b}$ & 50.73 & $88.67 \mathrm{~b}$ & $82.10 \mathrm{a}$ & $21.21 \mathrm{~b}$ & $95.36 \mathrm{a}$ & $2.86 \mathrm{a}$ & $65,92 \mathrm{~b}$ \\
\hline Average & - & 49.87 & - & - & - & - & - & - \\
\hline
\end{tabular}

Average followed by the same letter, in the columns, belong to the same group, according to the Scott-Knott test at $5 \%$. ${ }^{\text {ns }}$ Non-significant at $5 \%$ by the $\mathrm{F}$ test. $\mathrm{L} *$ : lightness; $\mathrm{C}^{*}$ : chroma; $\mathrm{h}^{*}$ : hue angle. 
peels (greater than 3.0). In our study, peel thickness and pulp yield were strongly negatively correlated $(\mathrm{R}=-0.85)$, so the fruits with thinner peels (BRS Caipira and YB 4203) had the highest pulp yield (above $76 \%$ ) (Table 2). The other genotypes presented yields below $69.21 \%$. Viana et al. (2013) evaluated 18 banana genotypes and found an average yield of $63.03 \%$ for the Prata Anã and Pacovan cultivars; $67.96 \%$ for FHIA18, Grand Naine, BRS Maravilha and BRS Caipira; and $78.65 \%$ for Thap Maeo. Pulp yield is an important parameter for food industries, since fruits with a higher pulp percentage are more profitable.

The pulp physicochemical traits of the banana genotypes are reported in Table 3 . The moisture varied from $69.41 \%$ (Pacovan) to $77.28 \%$ (PC 0101). Pacovan and Prata Anã had the lowest values $(69.41 \%$ and $70.02 \%$, respectively). These results corroborate those obtained by Jesus et al. (2004), who observed moisture values from $67.7 \%$ (Pacovan) to $71.4 \%$ (Prata Anã). Besides pulp yield, the water content of bananas influences the yield of concentrated and dehydrated products, so varieties with lower moisture levels are more attractive for making these products.

The soluble solids content provides an indication of the sugar concentration in the fruits. For this variable, the genotypes formed four groups. The Pacovan and Prata Anã commercial cultivars had the highest values, with $25.33^{\circ} \mathrm{Brix}$ and $27.17^{\circ} \mathrm{Brix}$, respectively (Table 3). Among the improved genotypes, the standouts were the BRS Maravilha and YB 4203 hybrids, with values of $22.92{ }^{\circ}$ Brix and $23.70{ }^{\circ}$ Brix, respectively. The genotypes with the lowest moisture levels (Pacovan and Prata Anã) presented the highest soluble solids contents, as also observed by Jesus et al. (2004). This finding was supported by the correlation analysis (data not shown), which revealed a significant negative correlation $(\mathrm{r}=-0.91)$ between these two variables. Genotypes with high soluble solids contents are desirable both for raw eating and processing.

There was no significant difference $(p>0.05)$ in pulp $\mathrm{pH}$, and the average of all the genotypes was 4.62. This value is similar to those reported by Bezerra \& Dias (2009), who found values between 4.6 (FHIA 18) and 5.1 (PV 03-44), and by Castricini et al. (2015), who observed variation from 4.2 (FHIA 18) to 4.71 (Prata Anã).

For titratable acidity, two groups were formed, one containing the Grand Naine and Prata Anã genotypes with the highest values $(0.81 \%$ and $0.76 \%$ of malic acid, respectively), and the others with levels between $0.43 \%$ and $0.65 \%$, without significant differences $(p>0.05)$. These results are similar to those reported by Viana et al. (2013), who found variation in malic acid content ranging from $0.58 \%$ to $0.83 \%$, in improved banana genotypes. However, much lower values were reported by Bezerra $\&$ Dias (2009), between $0.26 \%$ and $0.27 \%$.

The highest levels of total carotenoids were observed for the Pacovan (2.09 $\left.\mu \mathrm{g} \mathrm{g}^{-1}\right)$ and Grand Naine $\left(2.30 \mu \mathrm{g} \mathrm{g}^{-1}\right)$ commercial cultivars. The other genotypes did not differ $(p>0.05)$ among themselves, with values between $0.63 \mu \mathrm{g} \mathrm{g}^{-1}$ and $1.48 \mu \mathrm{g} \mathrm{g}^{-1}$. These results are in line with those of Viana et al. (2013), who found a range from $1.20 \mu \mathrm{g} \mathrm{g}^{-1}$ to $2.62 \mu \mathrm{g} \mathrm{g} \mathrm{g}^{-1}$, in improved and commercial genotypes. In turn, Amorim et al. (2011b) observed wide variation in 61 banana genotypes, with total carotenoids ranging between $1.18 \mu \mathrm{g} \mathrm{g}^{-1}$ (Champa Madras) and $19.24 \mu \mathrm{g} \mathrm{g}^{-1}$ (Saney). The authors also found that

Table 3. Fruit physicochemical traits of the banana genotypes.

\begin{tabular}{lccccc}
\hline \multicolumn{1}{c}{ Genotype } & $\begin{array}{c}\text { Moisture } \\
(\%)\end{array}$ & $\mathrm{pH}^{\mathrm{ns}}$ & $\begin{array}{c}\text { Soluble solids } \\
\left({ }^{\circ} \text { Brix }\right)\end{array}$ & $\begin{array}{c}\text { Titrable acidity } \\
(\% \text { malic acid })\end{array}$ & $\begin{array}{c}\text { Total carotenoids } \\
\left.(\mu \mathrm{g} \mathrm{g})^{-1}\right)\end{array}$ \\
\hline BRS Maravilha & $73.54 \mathrm{~b}$ & 4.41 & $22.92 \mathrm{c}$ & $0.59 \mathrm{~b}$ & $1.37 \mathrm{~b}$ \\
PC 0101 & $77.28 \mathrm{a}$ & 4.57 & $20.83 \mathrm{~d}$ & $0.56 \mathrm{~b}$ & $1.11 \mathrm{~b}$ \\
FHIA18 & $75.89 \mathrm{a}$ & 4.34 & $21.67 \mathrm{~d}$ & $0.56 \mathrm{~b}$ & $1.24 \mathrm{~b}$ \\
TM 2803 & $75.37 \mathrm{a}$ & 4.10 & $22.20 \mathrm{~d}$ & $0.59 \mathrm{~b}$ & $1.17 \mathrm{~b}$ \\
YB 4203 & $74.24 \mathrm{~b}$ & 4.35 & $23.70 \mathrm{c}$ & $0.61 \mathrm{~b}$ & $0.63 \mathrm{~b}$ \\
BRS Caipira & $76.21 \mathrm{a}$ & 4.73 & $21.33 \mathrm{~d}$ & $0.43 \mathrm{~b}$ & $1.03 \mathrm{~b}$ \\
Grand Naine & $76.79 \mathrm{a}$ & 4.58 & $21.67 \mathrm{~d}$ & $0.81 \mathrm{a}$ & $2.30 \mathrm{a}$ \\
Pacovan & $69.41 \mathrm{c}$ & 4.26 & $25.33 \mathrm{~b}$ & $0.65 \mathrm{~b}$ & $2.09 \mathrm{a}$ \\
Prata Anã & $70.02 \mathrm{c}$ & 4.34 & $27.17 \mathrm{a}$ & $0.76 \mathrm{a}$ & $1.48 \mathrm{~b}$ \\
\hline Average & - & 4.62 & - & - & - \\
\hline
\end{tabular}

Averages followed by the same letter, in the columns, belong to the same group, according to the Scott-Knott test at $5 \%$. ${ }^{\text {ns }}$ Non-significant at $5 \%$ by the F test. 
triploids with $\mathrm{AAB}$ and $\mathrm{ABB}$ genomic constitution presented higher levels of carotenoids than did AAA triploids. We did not observe that in this study.

The cluster analysis considering all the chromatic and physicochemical traits is presented in Figure 1. Two groups were formed: one containing the TM 2803 and PC 0101 tetraploids, while the other was formed by the FHIA 18, BRS Maravilha, YB 4203 and BRS Caipira improved genotypes and the Prata Anã, Grand Naine and Pacovan commercial cultivars. In a similar grouping analysis conducted by Viana et al. (2013), the FHIA 18, Grand Naine, BRS Maravilha and BRS Caipira genotypes were also grouped. However, those genotypes differed from the Pacovan and Prata Anã commercial cultivars, a result not found in our study. Furthermore, Jesus et al. (2004) observed that the FHIA18, Prata Anã

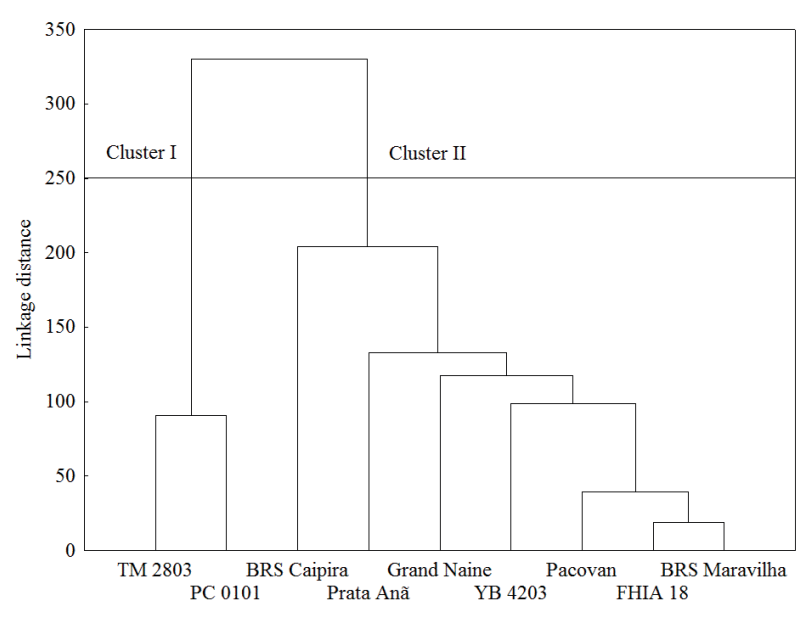

Figure 1. Dendrogram showing the generalized Mahalanobis distance between the banana genotypes, in relation to their chromatic and physicochemical traits. and Pacovan genotypes were not grouped. These divergent results can be explained by the different grouping techniques used in each study, as well as the physicochemical traits evaluated.

The results of the acceptance test and approval percentages (scores from 6 to 9) are presented in Table 4 . There was a significant difference $(p<0.05)$ between the genotypes for the five sensorial attributes assessed.

For color, the BRS Maravilha, PC 0101 and FHIA 18 genotypes and the Prata Anã and Grand Naine commercial cultivars received the highest scores (between 7.3 and 7.6) and approval ratings above $92 \%$. The YB 4203 genotype was the least accepted, with an average score of 6.2 and approval rating of $76 \%$.

The BRS Maravilha and TM 2803 improved genotypes and the Grand Naine and Prata Anã commercial cultivars obtained approval ratings above $92 \%$ for aroma and were classified between the hedonic scores "liked moderately" and "liked very much". The BRS Caipira and YB 4203 genotypes were the least accepted, in terms of aroma.

Regarding flavor, the BRS Maravilha and TM 2803 improved genotypes and the Prata Anã commercial variety were the most accepted, with approval ratings above $96 \%$. The PC 0101, FHIA 18, Pacovan and Grand Naine genotypes had well accepted flavors, with approval ratings between $84 \%$ and $92 \%$.

In terms of texture, the BRS Caipira and YB 4203 genotypes were the least accepted, with average scores of 6.4 and 6.3, respectively. The other genotypes did not differ significantly from each other $(p>0.05)$ for this attribute and were well accepted, with average scores higher than 7.2 and approval ratings above $86 \%$.

Table 4. Hedonic scores and approval percentages of the banana genotypes.

\begin{tabular}{lccccccccccc}
\hline \multirow{2}{*}{ Genotype } & \multicolumn{2}{c}{ Color } & \multicolumn{2}{c}{ Aroma } & \multicolumn{2}{c}{ Flavor } & \multicolumn{3}{c}{ Texture } & \multicolumn{2}{c}{ Overall acceptance } \\
\cline { 2 - 11 } & Score $^{1}$ & AP $^{2}$ & Score & AP & Score & AP & Score & AP & Score & AP \\
\hline BRS Maravilha & $7.6 \mathrm{a}$ & 98 & $7.7 \mathrm{a}$ & 100 & $7.6 \mathrm{a}$ & 98 & $7.4 \mathrm{a}$ & 94 & $7.7 \mathrm{a}$ & 98 \\
PC 0101 & $7.4 \mathrm{a}$ & 98 & $6.9 \mathrm{~b}$ & 90 & $7.0 \mathrm{~b}$ & 84 & $7.3 \mathrm{a}$ & 86 & $7.1 \mathrm{~b}$ & 88 \\
FHIA 18 & $7.3 \mathrm{a}$ & 98 & $6.9 \mathrm{~b}$ & 80 & $7.1 \mathrm{~b}$ & 96 & $7.2 \mathrm{a}$ & 100 & $7.3 \mathrm{~b}$ & 98 \\
TM 2803 & $6.9 \mathrm{~b}$ & 86 & $7.3 \mathrm{a}$ & 92 & $7.6 \mathrm{a}$ & 98 & $7.4 \mathrm{a}$ & 96 & $7.5 \mathrm{a}$ & 96 \\
YB 4203 & $6.2 \mathrm{c}$ & 76 & $6.0 \mathrm{~d}$ & 74 & $5.7 \mathrm{c}$ & 64 & $6.3 \mathrm{~b}$ & 78 & $5.9 \mathrm{c}$ & 72 \\
BRS Caipira & $6.7 \mathrm{~b}$ & 88 & $6.0 \mathrm{~d}$ & 72 & $5.8 \mathrm{c}$ & 66 & $6.4 \mathrm{~b}$ & 78 & $6.1 \mathrm{c}$ & 76 \\
Grand Naine & $7.3 \mathrm{a}$ & 92 & $7.4 \mathrm{a}$ & 94 & $7.3 \mathrm{~b}$ & 92 & $7.4 \mathrm{a}$ & 90 & $7.5 \mathrm{a}$ & 94 \\
Pacovan & $6.7 \mathrm{~b}$ & 86 & $6.6 \mathrm{c}$ & 74 & $6.9 \mathrm{~b}$ & 88 & $7.2 \mathrm{a}$ & 86 & $6.9 \mathrm{~b}$ & 84 \\
Prata Anã & $7.4 \mathrm{a}$ & 96 & $7.4 \mathrm{a}$ & 92 & $7.9 \mathrm{a}$ & 96 & $7.4 \mathrm{a}$ & 90 & $7.6 \mathrm{a}$ & 94 \\
\hline
\end{tabular}

${ }^{1}$ Averages $(\mathrm{n}=50)$ followed by the same letter, in the columns, belong to the same group, according to the Scott-Knott test at $5 \%$. ${ }^{2} \mathrm{AP}=\%$ of approval of the sensory attribute (scores from 6 to 9 ). 
Regarding overall acceptance, the BRS Maravilha and TM 2803 improved genotypes were equally well accepted, when compared to the Prata Anã and Grand Naine commercial cultivars, with scores above 7.5. The average acceptance ratings obtained in this study are higher than those reported by Garruti et al. (2012), for the Prata Anã, Grand Naine and Pacovan cultivars, which received scores between 6.0 and 7.0 for overall acceptance, aroma and flavor.

The BRS Caipira and YB 4203 genotypes received scores below 7.0 for all the attributes assessed. These results confirm those of Garruti et al. (2012), in which the BRS Caipira variety received the lowest scores for overall acceptance (5.73), aroma (5.57) and flavor (5.44).

To verify the influence of sensorial attributes on the overall acceptance of the bananas, a linear correlation analysis with these attributes was performed. The strongest significant positive correlation $(r=0.82, p<0.01)$ was between flavor and overall acceptance, meaning that flavor exerted the most influence on general acceptance. The second strongest positive correlation $(\mathrm{r}=0.72, \mathrm{p}<0.01)$ was between texture and overall acceptance.

When considering all five sensorial attributes assessed, the multivariate cluster analysis (Figure 2) indicated that the panel of tasters separated the genotypes into three clusters: cluster 1 , formed by the BRS Caipira and YB 4203 genotypes; cluster 2, formed by Pacovan, PC 0101 and FHIA 18; and cluster 3, with BRS Maravilha, TM 2803, Grand Naine and Prata Anã. According to the overall acceptance data (Table 4), the genotypes from the

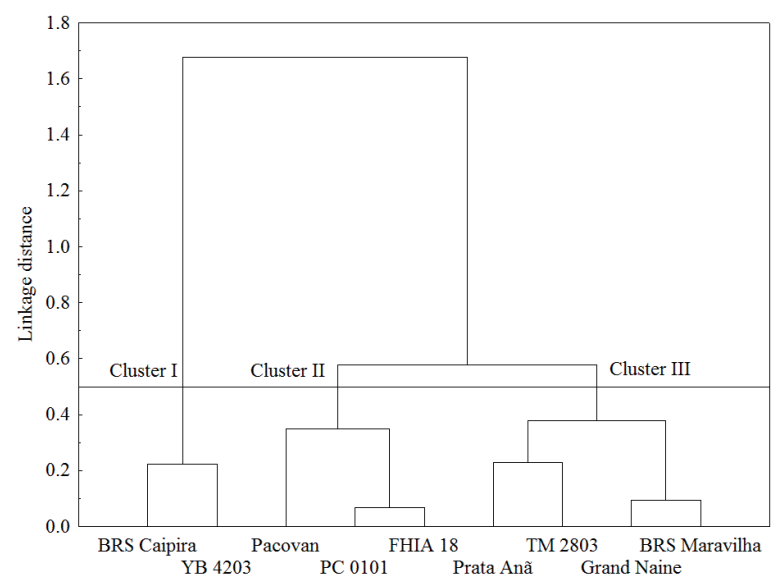

Figure 2. Dendrogram showing the generalized Mahalanobis distance between the banana genotypes, according to their sensory acceptance.

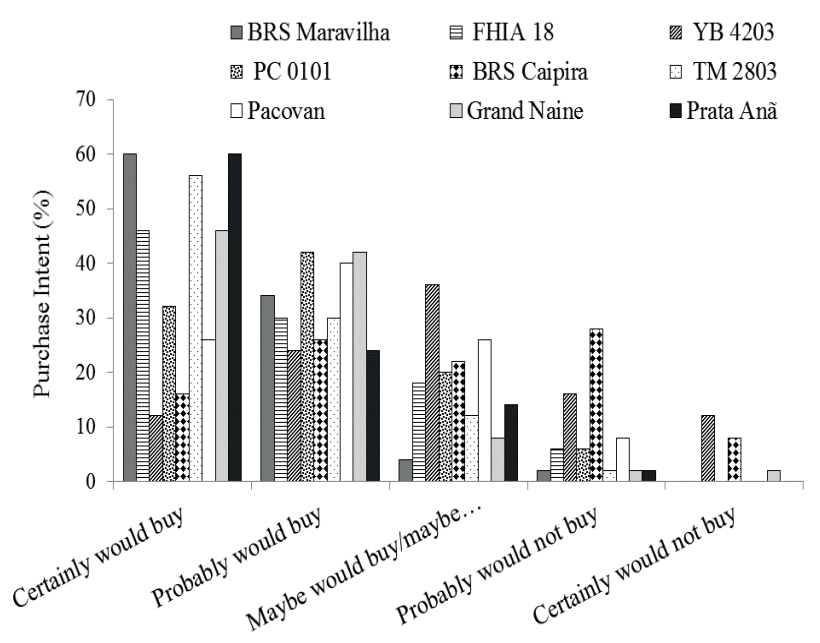

Figure 3. Purchase intent of the banana genotypes.

cluster 1 were the least accepted, followed by those from the cluster 2, with intermediate acceptance, while the cluster 3 had the highest acceptance rating. Furthermore, some genotypes considered similar, concerning the physicochemical traits (Figure 1), differed in relation to sensorial acceptance (Figure 2). These results indicate the importance of sensorial analysis as a tool to support genetic breeding programs in the selection of promising materials. This is because physicochemical characteristics similar to those of the commercial cultivars do not necessarily imply a good acceptance by consumers.

Finally, regarding the purchase intent, $60 \%$ of the tasters stated that they "certainly would buy" Prata Anã and BRS Maravilha bananas, and $56 \%$ said they "certainly would buy" TM2803 (Figure 3). On the other hand, BRS Caipira had the highest rejection rating, with $36 \%$ of the respondents stating they "certainly" or "probably" would not buy that variety. Low acceptance of this variety was also noted by Garrutti et al. (2012), in a study on the sensorial acceptance of banana cultivars in northeastern Brazil. According to the authors, this variety had the highest rejection rate, with $35 \%$ of respondents saying they "certainly" or "probably" would not buy these bananas.

\section{CONCLUSIONS}

1. The BRS Maravilha, BRS Caipira, YB 4203 and FHIA 18 genotypes presented similar physicochemical traits, when compared to the Pacovan, Prata Anã and Grand Naine commercial cultivars. 
2. Considering the sensorial attributes, the BRS Maravilha and TM 2803 genotypes had acceptance similar to the Prata Anã and Grand Naine commercial cultivars. Therefore, they are promising for commercial cultivation, with the advantage of being resistant to black Sigatoka and Panama disease.

\section{REFERENCES}

AGRITEMPO: sistema de monitoramento agrometeorológico. 2012. Available at: $<$ http://www. agritempo.gov. br/agroclima/sumario $>$. Acess on: $23 \mathrm{Jan}$. 2013.

AMORIM, E. P. et al. Caracterização de acessos de bananeira com base na concentração de compostos funcionais. Ciência Rural, Santa Maria, v. 41, n. 4, p. 592598,2011 b.

AMORIM, E. P. et al. Quality improvement of cultivated Musa. In: PILLAY, M.; TENKOUANO, A. (Orgs.). Banana breeding: progress and challenges. New York: CRC Press, 2011a. p. 252-280.

BEZERRA, V. S.; DIAS, J. S. A. Avaliação físico-química de frutos de bananeiras. Acta Amazonica, Manaus, v. 39, n. 2, p. 423- 428, 2009.

CASTRICINI, A. et al. Caracterização pós-colheita e sensorial de genótipos de bananeiras tipo Prata. Revista Brasileira de Fruticultura, Jaboticabal, v. 37, n. 1, p. $27-$ 37, 2015.

CRUZ, C. D. Programa Genes: análise multivariada e simulação. Viçosa: Ed. da UFV, 2006.

FERREIRA, D. F. Sisvar: sistema de análise de variância. Versão 5.3. Lavras: UFLa, 2010.

FOOD AND AGRICULTURE ORGANIZATION OF THE UNITED NATIONS (FAO). Faostat. 2014. Available at: < http://www.faostat3.fao.org> . Acess on: 20 Apr. 2016.

GARRUTI, D. S. et al. Aceitação de cultivares de bananas resistentes à Sigatoka Negra junto ao consumidor da região Nordeste do Brasil. Ciência Rural, Santa Maria, v. 42, n. 5, p. 948-954, 2012.

GONÇALVES, L. S. A. et al. Comparison of multivariate statistical algorithms to cluster tomato heirloom accessions. Genetics and Molecular Research, Ribeirão Preto, v. 7, n. 4, p. 1289-1297, 2008.

INSTITUTO ADOLFO LUTZ (IAL). Métodos físicoquímicos para análise de alimentos. 4. ed. Brasília, DF: Ministério da Saúde, 2008.
JESUS, S. C. et al. Caracterização física e química de frutos de diferentes genótipos de bananeira. Bragantia, Campinas, v. 63, n. 3, p. 315-323, 2004.

MATSUURA, F. C. A. U.; COSTA, J. I. P.; FOLEGATTI, M. I. S. Marketing de banana: preferências do consumidor quanto aos atributos de qualidade dos frutos. Revista Brasileira de Fruticultura, Jaboticabal, v. 26, n. 1, p. 4852, 2004.

MEILGAARD, M.; CIVILLE, G. V.; CARR, B. T. Sensory evaluation techniques. 4. ed. Boca Raton: CRC Press, 2006.

MINGOTI, S. A. Análise de dados através de métodos de estatística multivariada: uma abordagem aplicada. Belo Horizonte: UFMG, 2007.

NOMURA, E. S. et al. Avaliação agronômica de genótipos de bananeiras em condições subtropicais, Vale do Ribeira, São Paulo - Brasil. Revista Brasileira de Fruticultura, Jaboticabal, v. 35, n. 1, p. 112-122, 2013.

PERRIER, X. et al. Multidisciplinary perspectives on banana (Musa spp.) domestication. Proceedings of the National Academy of Sciences of the USA, Washington, DC, v. 108, n. 28, p. 1311-1318, 2011.

PROGRAMABRASILEIRO PARAAMODERNIZAÇÃO DAHORTICULTURA\& PRODUÇÃO INTEGRADADE FRUTAS (PBMH \& PIF). Normas de classificação de banana. São Paulo: Ceagesp, 2006.

R DEVELOPMENT CORE TEAM (RDCT). $R$ : a language and environment for statistical computing.Vienna: R Foundation for Statistical Computing, 2005.

RAMALLO, L. A.; MASCHERONI, R. H. Quality evaluation of pineapple fruit during drying process. Food and Bioproducts Processing, London, v. 90, n. 2 , p. 275283, 2012.

RODRIGUEZ-AMAYA, D.; KIMURA, M. Harvest plus handbook for carotenoid analysis. Washington, DC: IFPRI, 2004.

ROQUE, R. L. et al. Desempenho agronômico de genótipos de bananeira no Recôncavo da Bahia. Revista Brasileira de Fruticultura, Jaboticabal, v. 36, n. 3, p. 598609, 2014.

SILVA, S. O. et al. Melhoramento genético da bananeira: estratégias e tecnologias disponíveis. Revista Brasileira de Fruticultura, Jaboticabal, v. 35, n. 3, p. 919-931, 2013.

TACO: tabela brasileira de composição de alimentos. 4.ed. Campinas: NEPA-Unicamp, 2011.

VIANA, E. S. et al. Physico-chemical evaluation of fruit of improved banana cultivars in Brazil by multivariate analysis. Acta Horticulturae, Leuven, n. 986, p. 301-308, 2013. 